\title{
Respiratory symptoms associated with low level sulphur dioxide exposure in silicon carbide production workers
}

\author{
J W OSTERMAN, ${ }^{123}$ I A GREAVES, ${ }^{1}$ T J SMITH,' S K HAMMOND,' \\ J M ROBINS,' G THÉRIAULT ${ }^{2}$
}

From the Department of Environmental Science and Physiology, ${ }^{\prime}$ Harvard School of Public Health, Boston, Mass, USA, and School of Occupational Health, ${ }^{2}$ McGill University, Montreal, and Community Health Department, ${ }^{3}$ Lakeshore General Hospital, Pointe-Claire, Quebec, Canada

ABSTRACT Relations between pulmonary symptoms and exposure to respirable dust and sulphur dioxide $\left(\mathrm{SO}_{2}\right)$ were evaluated for 145 silicon carbide $(\mathrm{SiC})$ production workers with an average of 13.9 (range 3-41) years of experience in this industry. Eight hour time weighted average exposures to $\mathrm{SO}_{2}$ were $1.5 \mathrm{ppm}$ or less with momentary peaks up to $4 \mathrm{ppm}$. Cumulative $\mathrm{SO}_{2}$ exposure averaged 1.94 (range 0.02-19.5) ppm-years. Low level respirable dust exposures also occurred $\left(0.63 \pm 0.26 \mathrm{mg} / \mathrm{m}^{3}\right)$. After adjusting for age and current smoking status in multiple logistic regression models, highly significant, positive, dose dependent relations were found between cumulative and average exposure to $\mathrm{SO}_{2}$, and symptoms of usual and chronic phlegm, usual and chronic wheeze, and mild exertional dyspnoea. Mild and moderate dyspnoea were also associated with most recent exposure to $\mathrm{SO}_{2}$. Cough was not associated with $\mathrm{SO}_{2}$. No pulmonary symptoms were associated with exposure to respirable dust nor were any symptoms attributable to an interaction between dust and $\mathrm{SO}_{2}$. Cigarette smoking was strongly associated with cough, phlegm, and wheezing, but not dyspnoea. A greater than additive (synergistic) effect between smoking and exposure to $\mathrm{SO}_{2}$ was present for most symptoms. These findings suggest that long term, variable exposure to $\mathrm{SO}_{2}$ at $1.5 \mathrm{ppm}$ or less was associated with significantly raised rates of phlegm, wheezing, and mild dyspnoea in SiC production workers, and that current threshold limits for $\mathrm{SO}_{2}$ may not adequately protect workers in this industry.

Silicon carbide $(\mathrm{SiC})$ production workers are exposed to an array of respirable contaminants with known or suspected human toxicity. These include: crystalline silica used as a primary reagent; furnace emissions containing polycyclic aromatic hydrocarbons (PAH), sulphur dioxide $\left(\mathrm{SO}_{2}\right)$, and carbon monoxide; graphite used as an electric conductor; and large volumes of dust containing $\mathrm{SiC}$, hydrocarbons, quartz, and cristobalite which is produced when workers crush blocks of newly formed $\mathrm{SiC}$ with hand held pneumatic tools. Estimated exposures to all these contaminants have been published elsewhere. ${ }^{1-3}$

Although several investigators have described radiographic densities ${ }^{3-6}$ and a restrictive pattern of pulmonary function $\operatorname{loss}^{3-5}$ consistent with the development of pneumoconiosis among these workers, pulmonary symptoms in SiC workers have not previously been evaluated. In this paper we present Accepted 24 October 1988 findings on the relation between pulmonary symptoms and exposures in $\mathrm{SiC}$ production.

\section{Methods}

SUBJECTS

From union membership lists we identified $177 \mathrm{SiC}$ workers with at least two years experience who had been employed some time between 1977 and 1982 . Five workers refused to participate, three retired and two laid off workers were unavailable, and two disabled workers were excluded. Exposure records were not available for 20 workers, leaving a final study group of 145 men.

\section{HEALTH EFFECTS}

Information on respiratory symptoms, illnesses, relevant medical history, and smoking habits was obtained through the administration by one of three 
trained interviewers of a French translation ${ }^{7}$ of the American Thoracic Society (ATS) respiratory disease questionnaire. ${ }^{8}$ Workers also completed forms describing past employment in other industries, the period worked in $\mathrm{SiC}$ manufacture, and specific questions about employment in 15 dusty trades. A semiquantitative estimate of cough frequency was obtained by administering a cough questionnaire developed by Field. ${ }^{9}$ Workers were also asked to grade their subjective feeling of dyspnoea on a linear scale. ${ }^{10}$ A physical examination of the respiratory and cardiovascular systems was performed by one of us (JWO), without knowledge of exposure history, pulmonary function, or responses to questionnaire. The physical examination included an evaluation of productive cough on request, ${ }^{11}$ during which each worker was asked to cough deeply, and presence or absence of loose phlegm was ascertained according to the sound produced. Pulmonary function tests were performed according to ATS guidelines ${ }^{8}$ and are reported elsewhere. ${ }^{3}$

\section{AIRBOR NE EXPOSURES}

Job specific exposure measurements of airborne contaminants in this $\mathrm{SiC}$ production factory were obtained in 1980 and 1983, and are reported elsewhere.$^{3}$ Company records included job titles, dates, and time off for each worker's entire period of employment at the factory. From this information we could construct cumulative exposure indices for respirable dust and $\mathrm{SO}_{2}$, calculated from the product of time spent at each job assignment and the job specific exposure level, summed over all job categories that the worker had occupied, and measured in units of concentration-time $\left(\mathrm{mg}\right.$-year $/ \mathrm{m}^{3}$ for cumulative dust and $\mathrm{ppm}$-year for cumulative $\mathrm{SO}_{2}$ ). Each worker's average exposure to dust $\left(\mathrm{mg} / \mathrm{m}^{3}\right)$ or $\mathrm{SO}_{2}(\mathrm{ppm})$ was obtained by dividing his cumulative exposure by the duration of his employment. We also obtained the job specific $\mathrm{SO}_{2}$ exposure level (ppm) for the most recent position held; this measure was used in place of current $\mathrm{SO}_{2}$ exposure because the plant had been closed during the six months preceding our study.

\section{DATA ANALYSIS}

Questionnaire, lung function, and exposure data were coded and entered into an IBM 360 computer, and were extensively checked to ensure completeness and accuracy. Descriptive statistics, correlation matrices, analysis of variance, multiple logistic and linear regressions, and corresponding tests of significance were performed with a standard statistical package (Statistical Analysis System Inc, Cary, NC, 1982). Chisquared statistics were used to measure the statistical significance of individual coefficients in the logistic regression models. Two tailed Student's $t$ test and the

Table 1 Age, smoking, and exposure data for 145 silicon carbide workers

Age (y)

Never smokers (\%)

Ex-smokers (\%)

Current smokers (\%)

Pack-years*

Years worked

Cumulative dust exposure (mg-year $/ \mathrm{m}^{3}$ )

Average dust exposure $\left(\mathrm{mg} / \mathrm{m}^{3}\right)$

Cumulative $\mathrm{SO}_{2}$ exposure (ppm-years)

Average $\mathrm{SO}_{2}$ exposure (ppm)

Most recent $\mathrm{SO}_{2}$ exposure (ppm)

Values are mean \pm SD

*Excluding non-smokers. One pack-year is equivalent to one packof 20 cigarettes smoked a day throughout one year.

Mantel-Haenszel chi-squared statistic were used toळ compare various descriptive results. ${ }^{12}$ To control for 3 confounding by age and smoking habit, as well as to differentiate between the effects of work duration, 6 dust, and exposure to $\mathrm{SO}_{2}$, logistic regression models were used to evaluate most of our symptoms data. Step up and step down procedures were used to determine ${ }^{-}$ the best regression models in terms of simplicity, $\vec{c}$ analysis of residuals, statistical significance, and $\mathbb{D}$ variance explained. ${ }^{12}$

\section{Results}

The final study group consisted of 145 white Frencb- $\vec{\bullet}$ Canadian men with an average age of 39.6 (range 280 65 ) years and 14 years (range 3-41) experience in to industry (table 1). Thirty one workers had nevês smoked cigarettes; ex-smokers and current smokers had smoked similar amounts. Other tobacco products

Table 2 Definitions of respiratory symptoms obtained by questionnaire

\begin{tabular}{|c|c|}
\hline Symptom & Definition \\
\hline Usual cough & $\begin{array}{l}\text { Positive response to "Do you usually have } \\
\text { cough?" }\end{array}$ \\
\hline Usual phlegm & $\begin{array}{l}\text { Positive response to "Do you usually bring } \\
\text { up phlegm from your chest (not from } \\
\text { back of your nose)?" }\end{array}$ \\
\hline Chronic phlegm & $\begin{array}{l}\text { Positive response to "Do you bring up } \\
\text { phlegm like this on most days for three } \\
\text { consecutive months or more during the } \\
\text { year?" and a response of more than two } \\
\text { years to "For how many years have you } \\
\text { had this phlegm?" }\end{array}$ \\
\hline $\begin{array}{l}\text { Wheezing most days } \\
\text { or nights }\end{array}$ & $\begin{array}{l}\text { Positive response to "Does your chest ever } \\
\text { sound wheezy or whistling? Most days or } \\
\text { nights?" }\end{array}$ \\
\hline Chronic wheezing & $\begin{array}{l}\text { Positive response to wheezing most days or } \\
\text { nights and a response of more than two } \\
\text { years to "For how many years has this } \\
\text { been present?" }\end{array}$ \\
\hline $\begin{array}{l}\text { Dyspnoea while } \\
\text { hurrying }\end{array}$ & $\begin{array}{l}\text { Positive response to "Are you troubled by } \\
\text { shortness of breath when hurrying on the } \\
\text { level or walking up a slight hill?" }\end{array}$ \\
\hline $\begin{array}{l}\text { Dyspnoea keeping up } \\
\text { with peers }\end{array}$ & $\begin{array}{l}\text { Positive response to "Do you have to walk } \\
\text { slower than people of your own age on } \\
\text { the level because of breathlessness?" }\end{array}$ \\
\hline
\end{tabular}


Table 3 Prevalence (\%) of respiratory symptoms by current smoking status for 145 silicon carbide workers

\begin{tabular}{lllll}
\hline & $\begin{array}{l}\text { Never smokers } \\
(n=31)\end{array}$ & $\begin{array}{l}\text { Ex-smokers } \\
(n=36)\end{array}$ & $\begin{array}{l}\text { Current smokers } \\
(n=78)\end{array}$ & $\begin{array}{l}\text { Entire cohort } \\
(n=145)\end{array}$ \\
\hline Usual cough & $9 \cdot 7$ & 13.9 & $53 \cdot 8$ & $34 \cdot 5$ \\
Usual phlegm & $19 \cdot 3$ & $33 \cdot 3$ & $47 \cdot 4$ & $37 \cdot 9$ \\
Chronic phlegm & $16 \cdot 1$ & $19 \cdot 4$ & $32 \cdot 1$ & $25 \cdot 5$ \\
Wheezing on most days/nights & $16 \cdot 1$ & 13.9 & $32 \cdot 3$ & $26 \cdot 2$ \\
Chronic wheezing & $16 \cdot 1$ & $11 \cdot 1$ & $37 \cdot 2$ & $48 \cdot 3$ \\
Dyspnoea when hurrying & $45 \cdot 2$ & $41 \cdot 7$ & $52 \cdot 6$ & $14 \cdot 5$ \\
Dyspnoea keeping up with peers & $12 \cdot 9$ & $11 \cdot 1$ & 16.7 & \\
\hline
\end{tabular}

were used infrequently and generally by cigarette smokers.

\section{EXPOSURE}

The workforce had a mean cumulative dust exposure of $9.5 \mathrm{mg}$-years $/ \mathrm{m}^{3}$ (range $0.6-39.7$ ) and was exposed on average to $0.63 \mathrm{mg} / \mathrm{m}^{3}$ of dust while employed (table 1). Exposure to $\mathrm{SO}_{2}$ was low; personal and area samples indicated that furnace workers were exposed to levels of $1.0-1.5 \mathrm{ppm}$ (eight hour TWA), while carboselectors, preparation, maintenance, and other workers were exposed to $0.2 \mathrm{ppm}$ or less. Occasional instantaneous peaks up to $4 \mathrm{ppm}$ were measured in the furnace area by indicator tubes. No worker had a mean $\mathrm{SO}_{2}$ exposure of more than $1 \mathrm{ppm}$ while employed. Cumulative exposure to $\mathrm{SO}_{2}$ was also low, averaging less than 2 ppm-years (range 0.02-19.5). Most recent exposure to $\mathrm{SO}_{2}$ averaged $0.26 \mathrm{ppm}$ (range $0-1.5$ ) with $20 \%$ of the workforce exposed to one ppm or more (eight hour TWA).

\section{SMOKING}

The prevalence of the seven symptoms defined in table 2 was analysed by smoking habit for the entire study group (table 3 ). Other symptoms obtained from the ATS questionnaire but not included in table 2 occurred infrequently (severe dyspnoea, wheezing attacks, chest colds) or gave similar results to the symptoms presented (other questions pertaining to cough and phlegm). With the exception of "usual phlegm," where a twofold, non-significant difference was present, the prevalence of symptoms was similar among never and ex-smokers; never and ex-smokers were therefore considered together as non-smokers in subsequent analyses. All symptoms occurred more frequently in current smokers.

After adjusting for age and occupational exposures by multiple logistic regression, current smoking habit was found to be strongly related to cough, phlegm, and wheeze, but only slightly related to mild dyspnoea (tables 4-6). Cigarettes smoked a day showed a similar but weaker association, whereas variables which included past cigarette smoking (years smoked, packyears) were poorly related to symptoms. In order to maximally control potential confounding from cigarettes, the current smoking/non-smoking categorical variable was retained for regression models evaluating relations between pulmonary symptoms and occupational exposures.

Table 4 Odds ratios from multiple logistic regression models for various symptoms on categories of cumulative SO $\mathrm{S}_{2}$ exposure, current smoking, and age

\begin{tabular}{|c|c|c|c|c|c|c|}
\hline & \multicolumn{5}{|c|}{ Cumulative sulphur dioxide exposure category (ppm-years) } & \multirow[b]{2}{*}{ Age } \\
\hline & $\begin{array}{l}0-0 \cdot 25 \\
(n=35)\end{array}$ & $\begin{array}{l}>0 \cdot 25-1 \cdot 00 \\
(n=47)\end{array}$ & $\begin{array}{l}>1.00-3 \cdot 00 \\
(n=37)\end{array}$ & $\begin{array}{l}>3 \cdot 0 \\
(n=26)\end{array}$ & $\begin{array}{l}\text { Current smokers } \\
(n=78)\end{array}$ & \\
\hline Usual cough & 1.00 & 1.44 & $2 \cdot 36$ & 1.73 & $12 \cdot 1 \S$ & $p=0.06$ \\
\hline Usual phlegm & 1.00 & $\begin{array}{l}1.26 \\
(0.45-3.51)\end{array}$ & $\begin{array}{l}2.85^{*} \\
(0.93-8.78)\end{array}$ & $\begin{array}{l}5.47 \dagger \\
(1.45-20.6)\end{array}$ & $\begin{array}{l}2.65 \pm \\
(1.26-5.58)\end{array}$ & NS \\
\hline Chronic phlegm & $1 \cdot 00$ & $\begin{array}{l}1.43 \\
(0.42-4.83)\end{array}$ & $\begin{array}{l}2.94^{*} \\
(0.84-10 \cdot 3)\end{array}$ & $\begin{array}{l}11.8 \pm \\
(2.58-52.9)\end{array}$ & $\begin{array}{l}2.40 \dagger \\
(1.03-5.47)\end{array}$ & NS \\
\hline Wheezing on most days or nights & 1.00 & $\begin{array}{l}3.46 \dagger \\
(1.02-11.6)\end{array}$ & $\begin{array}{l}4 \cdot 18 \dagger \\
(1 \cdot 14-15 \cdot 2)\end{array}$ & $\begin{array}{l}8 \cdot 17^{\ddagger} \\
(5 \cdot 51-36 \cdot 9)\end{array}$ & $\begin{array}{l}5 \cdot 31 \S \\
(2 \cdot 24-12 \cdot 6)\end{array}$ & NS \\
\hline Chronic wheezing & $1 \cdot 00$ & $\begin{array}{l}4.79+ \\
(1.15-19.9)\end{array}$ & $\begin{array}{l}7 \cdot 57 \ddagger \\
(1 \cdot 72-33 \cdot 0)\end{array}$ & $\begin{array}{l}12 \cdot 3+ \\
(2 \cdot 28-65 \cdot 0)\end{array}$ & $\begin{array}{l}4.88 \S \\
(2.01-11 \cdot 9)\end{array}$ & NS \\
\hline Dyspnoea while hurrying & 1.00 & $\begin{array}{l}3.16^{+} \\
(1.12-8.92)\end{array}$ & $\begin{array}{l}2.07 \\
(0.65-6.50)\end{array}$ & $\begin{array}{l}8.58_{+}^{+} \\
(2.03-35 \cdot 9)\end{array}$ & $\begin{array}{l}2.09^{*} \\
(0.98-4.45)\end{array}$ & $p=0.03$ \\
\hline Dyspnoea keeping up with peers & 1.00 & $\begin{array}{l}1.65 \\
(0.28-9.65)\end{array}$ & $\begin{array}{l}1.87 \\
(0.32-10.9)\end{array}$ & $\begin{array}{l}3.46 \\
(0.55-23.6)\end{array}$ & $\begin{array}{l}1.83 \\
(0.66-5.03)\end{array}$ & $p=0.08$ \\
\hline
\end{tabular}

Odds ratios for $\mathrm{SO}_{2}$ exposure are relative to workers exposed to $0-0 \cdot 25 \mathrm{ppm}$-years after adjusting for smoking and age. Ranges of values in parentheses indicate $95 \%$ CI for the odds ratio.

$p$ Values were obtained from the chi-squared statistic for each odds ratio.

${ }^{*} 0.05 \leqslant p<0.10 ;+0.01 \leqslant p<0.05 ; \ddagger 0.001 \leqslant p<0.01 ; \S p<0.001$. 
Table 5 Odds ratios from multiple logistic regression models for various symptoms on categories of average $\mathrm{SO}_{2}$ exposure while employed, current smoking, and age

\begin{tabular}{|c|c|c|c|c|c|c|}
\hline & \multicolumn{5}{|c|}{ Average sulphur dioxide exposure category (ppm) } & \multirow[b]{2}{*}{ Age } \\
\hline & $\begin{array}{l}0-0.05 \\
(n=57)\end{array}$ & $\begin{array}{l}>0.05-0.10 \\
(n=38)\end{array}$ & $\begin{array}{l}>0 \cdot 10-0 \cdot 20 \\
(n=24)\end{array}$ & $\begin{array}{l}>0 \cdot 20 \\
(n=26)\end{array}$ & $\begin{array}{l}\text { Current smokers } \\
(n=78)\end{array}$ & \\
\hline Usual cough & 1.00 & 0.81 & $\begin{array}{l}1.90 \\
(0.62-5.85)\end{array}$ & $\begin{array}{l}1.25 \\
0.40-3.91)\end{array}$ & $10 \cdot 3 \S$ & $\mathrm{p}=0.01$ \\
\hline Usual phlegm & 1.00 & $\begin{array}{l}(0.28-2 \cdot 31) \\
1.12 \\
(0.45-2 \cdot 84)\end{array}$ & $\begin{array}{c}(0.02-5.83) \\
3.49 \dagger \\
(1.23-9.86)\end{array}$ & $\begin{array}{l}\left(0.54^{*}\right. \\
(0.93-6.89)\end{array}$ & $\begin{array}{l}(3.91-20.1) \\
2.20 \dagger \\
(1.05-4.64)\end{array}$ & NS \\
\hline Chronic phlegm & 1.00 & $\begin{array}{l}0.67 \\
(0.21-2 \cdot 15)\end{array}$ & $\begin{array}{l}2.61 * \\
(0.89-7.67)\end{array}$ & $\begin{array}{l}3.25 \dagger \\
(1.13-9.38)\end{array}$ & $\begin{array}{l}1.89 \\
(0.82-4 \cdot 37)\end{array}$ & NS \\
\hline Wheezing on most days or nights & 1.00 & $\begin{array}{l}1.52 \\
(0.53-4.30)\end{array}$ & $\begin{array}{l}2.48^{*} \\
(0.83-7.44)\end{array}$ & $\begin{array}{l}3.78 \dagger \\
(1.26-11 \cdot 3)\end{array}$ & $\begin{array}{l}4.48 \S \\
(1.87-10.7)\end{array}$ & NS \\
\hline Chronic wheezing & 1.00 & $\begin{array}{l}2 \cdot 64^{*} \\
(0 \cdot 85-8 \cdot 22)\end{array}$ & $\begin{array}{l}4.39 \dagger \\
(1.35-14 \cdot 2)\end{array}$ & $\begin{array}{l}5.41 \ddagger \\
(1.67-17.6)\end{array}$ & $\begin{array}{l}4.13 \ddagger \\
(1.65-10 \cdot 4)\end{array}$ & NS \\
\hline Dyspnoea while hurrying & 1.00 & $\begin{array}{l}1.40 \\
(0.58-3.39)\end{array}$ & $\begin{array}{l}1.78 \\
(0.63-5.03)\end{array}$ & $\begin{array}{l}3.00 \dagger \\
(1.06-8.49)\end{array}$ & $\begin{array}{l}1.67 \\
(0.80-3.51)\end{array}$ & $p=0.000$ \\
\hline Dyspnoea keeping up with peers & 1.00 & $\begin{array}{l}0.44 \\
(0.08-2.37)\end{array}$ & $\begin{array}{l}2.15 \\
(0.57-8 \cdot 11)\end{array}$ & $\begin{array}{l}2.28 \\
(0.64-8.09)\end{array}$ & $\begin{array}{l}1 \cdot 46 \\
(0 \cdot 50-4 \cdot 22)\end{array}$ & $p=0.01$ \\
\hline
\end{tabular}

Odds ratios for $\mathrm{SO}_{2}$ exposure are relative to workers exposed to an average of $0-0.05 \mathrm{ppm}$ throughout their entire period of employment aftel adjusting for smoking and age. Range of values in parentheses indicate $95 \%$ CI for the odds ratio. p Values were obtained from the chis? squared statistic for each odds ratio.

$* 0.05 \leqslant p<0.10 ;+0.01 \leqslant p<0.05 ; \ddagger 0.001 \leqslant p<0.01 ; \S p<0.001$.

\section{SULPHUR DIOXIDE}

A strong, positive, and approximately linear, dose dependent relation was found between several symptoms and both cumulative (table 4 ) and average (table 5) $\mathrm{SO}_{2}$ exposure while employed. Workers in the highest exposure categories had significantly increased rates of usual phlegm. This association was stronger for the more stringently defined symptom of chronic phlegm. Usual phlegm appeared to be principally related to exposure duration $(\mathrm{p}<0.02)$, rather than exposure level $(p>0.10)$; this relation, however, was reversed for chronic phlegm (exposure level: $\mathrm{p}<$ 0.001 , exposure duration: $p>0 \cdot 10$ ).

A strong association was present between exposure to $\mathrm{SO}_{2}$ and usual wheeze, which also became greater for the more stringently defined symptom of chronic wheeze. Wheezing was primarily associated with exposure level $(p<0.04)$ and was not associated with duration of exposure.
Mild dyspnoea (while hurrying) was found ton increase with exposure to $\mathrm{SO}_{2}$, and significant odd 8 ratios occurred in the highest $\mathrm{SO}_{2}$ exposure categories Moderate dyspnoea (keeping up with peers) followe a similar and generally linear trend but was not statistically significant. More severe dyspnge $\vec{b}$ occurred too infrequently to be analysed. Mild dipo noea was associated with exposure level $(\mathrm{p}<0.05)$ t.it not work duration. Age, however, was the ris important factor related to dyspnoea.

Dyspnoea was also evaluated on a linear sca proposed by Gandevia. ${ }^{10}$ After adjusting for age anf current smoking status by multiple regression, eacR ppm of average $\mathrm{SO}_{2}$ exposure was associated with $\vec{\oplus}$ $20 \%$ reduction in self perceived respiratory function $(\mathrm{p}=0.06)$.

Cough was not associated with exposure to $\mathrm{SO}_{2}$ bui? was associated primarily with current smoking hab and to a lesser extent with age. Similar results were

Table 6 Odds ratios from multiple logistic regression models for various symptoms on categories of most recent SO, exposure, current smoking, and age

\begin{tabular}{|c|c|c|c|c|c|}
\hline & \multicolumn{4}{|c|}{ Recent sulphur dioxide exposure category } & \\
\hline & $\begin{array}{l}0-1 \mathrm{ppm} \\
(n=115)\end{array}$ & $\begin{array}{l}\geqslant 1 p p m \\
(n=30)\end{array}$ & $\begin{array}{l}\text { Current smokers } \\
(n=78)\end{array}$ & Age & \\
\hline $\begin{array}{l}\text { Usual cough } \\
\text { Usual phlegm } \\
\text { Chronic phlegm } \\
\text { Wheezing on most days or nights } \\
\text { Chronic wheezing } \\
\text { Dyspnoea while hurrying } \\
\text { Dyspnoea keeping up with peers }\end{array}$ & $\begin{array}{l}1.00 \\
1.00 \\
1.00 \\
1.00 \\
1.00 \\
1.00 \\
1.00\end{array}$ & $\begin{array}{ll}1.00 & (0.38-2.65) \\
0.88 & (0.37-2.67) \\
1.58 & (0.65-3.83) \\
1.79 & (0.73-4.40) \\
1.89 & (0.76-4.72) \\
2.06 * & (0.87-4.89) \\
3.58 \dagger & (1.22-10.5)\end{array}$ & $\begin{array}{cl}11.6 \$ & (4.43-30.3) \\
2.58 \ddagger & (1.27-5.26) \\
2.16^{*} & (0.98-4.77) \\
4.48 \S & (1.95-10.3) \\
4.18 \ddagger & (1.76-9.90) \\
1.67 & (0.83-3.39) \\
1.68 & (0.61-4.66)\end{array}$ & $\begin{array}{l}p=0.005 \\
N S \\
N S \\
p=0.08 \\
p=0.05 \\
p=0.0001 \\
p=0.002\end{array}$ & $\begin{array}{l}\text { O } \\
N \\
0 \\
\omega \\
\sigma \\
\sigma\end{array}$ \\
\hline
\end{tabular}

Odds ratios for $\mathrm{SO}_{2}$ exposures are relative to workers with most recent exposures of less than 1 ppm after adjusting for smoking and ag. Ranges of values in parentheses indicate $95 \% \mathrm{CI}$ for the odds ratio. p Values were obtained from the chi-squared statistic for each odds rati $6+$ $* 0.05 \leqslant p<0.10 ;+0.01 \leqslant p<0.05 ;+0.001 \leqslant p<0.01 ; \S p<0.001$. 
Table 7 Prevalence of various symptoms (\%) classified by current smoking habit and average exposure to $\mathrm{SO}_{2}$ while employed for 145 silicon carbide workers

\begin{tabular}{|c|c|c|c|}
\hline Symptom & $\begin{array}{l}\text { Average } \mathrm{SO}_{2} \\
\text { exposure } \\
\text { level } \\
(\text { ppm })\end{array}$ & $\begin{array}{l}\text { Non and } \\
\text { ex-smokers }\end{array}$ & $\begin{array}{l}\text { Current } \\
\text { smokers }\end{array}$ \\
\hline Usual cough & $\begin{aligned} & 0-0.1 \\
> & 0.1\end{aligned}$ & $\begin{array}{l}12 \cdot 2 \\
11 \cdot 1\end{array}$ & $\begin{array}{l}43 \cdot 5 \\
68.8\end{array}$ \\
\hline Usual phlegm & $\begin{aligned} & 0-0.1 \\
> & 0.1\end{aligned}$ & $\begin{array}{l}24 \cdot 5 \\
33 \cdot 3\end{array}$ & $\begin{array}{l}32 \cdot 6 \\
68 \cdot 8\end{array}$ \\
\hline Chronic phlegm & $\begin{aligned} & 0-0.1 \\
> & 0.1\end{aligned}$ & $\begin{array}{l}14 \cdot 3 \\
27 \cdot 8\end{array}$ & $\begin{array}{l}19 \cdot 6 \\
50 \cdot 0\end{array}$ \\
\hline $\begin{array}{l}\text { Wheezing most days or } \\
\text { nights } \\
\text { Chronic wheezing }\end{array}$ & $\begin{aligned} & 0-0.1 \\
> & 0.1 \\
& 0-0.1 \\
> & 0.1\end{aligned}$ & $\begin{array}{r}10 \cdot 2 \\
27 \cdot 8 \\
8 \cdot 2 \\
27 \cdot 8\end{array}$ & $\begin{array}{l}32 \cdot 6 \\
56 \cdot 3 \\
26 \cdot 1 \\
53 \cdot 1\end{array}$ \\
\hline $\begin{array}{l}\text { Dyspnoea while } \\
\text { hurrying } \\
\text { Dyspnoea keeping up } \\
\text { with peers }\end{array}$ & $\begin{aligned} & 0-0.1 \\
> & 0.1 \\
& 0-0.1 \\
> & 0.1\end{aligned}$ & $\begin{array}{r}36 \cdot 7 \\
61 \cdot 1 \\
8 \cdot 1 \\
22 \cdot 2\end{array}$ & $\begin{array}{r}43 \cdot 5 \\
65 \cdot 6 \\
8 \cdot 7 \\
28 \cdot 1\end{array}$ \\
\hline
\end{tabular}

Non-smokers and ex-smokers were respectively 31 and $36 ; 78$ workers currently smoked, and 95 workers were exposed, on average, to less than $0.1 \mathrm{ppm} \mathrm{SO}_{2}$ while employed.

obtained from the semiquantitative cough scale developed by Field. ${ }^{8}$ Productive cough on request was related to smoking $(\mathrm{OR}=3.8 ; \mathrm{p}<0.001)$ but not to $\mathrm{SO}_{2}$ exposure.

Plant closure prevented the study group from working during the six months preceding our health evaluation, so we could not assess symptoms with respect to current exposure to $\mathrm{SO}_{2}$. Instead, we analysed symptoms and job specific $\mathrm{SO}_{2}$ exposure levels for the most recent position held (table 6). The 30 workers exposed to $1 \mathrm{ppm}$ or more of $\mathrm{SO}_{2}$ on their last day at work had slightly increased odds ratios for most symptoms, although significant results were found only for dyspnoea keeping up with peers.

\section{RESPIRABLE DUST}

Unlike $\mathrm{SO}_{2}$, cumulative and average exposures to respirable dust rarely contributed to the logistic regression models used to evaluate pulmonary symptoms in this population of $\mathrm{SiC}$ workers. When analysed independently of $\mathrm{SO}_{2}$, cumulative dust exposure was significantly associated with chronic wheeze in the $10-20 \mathrm{mg}$-years $/ \mathrm{m}^{3}$ exposure category $(O R=3.45 ; p<0.05)$, and non-significant odds ratios greater than one were present for most symptom-exposure categories. A slight, non-significant association also was present between average dust exposure and symptoms of usual phlegm, wheeze, and dyspnoea keeping up with peers. In regression models which included dust and $\mathrm{SO}_{2}$ exposure variables simultaneously, however, dust had no effect and all dust symptom associations were small and non-significant. The strong, highly significant $\mathrm{SO}_{2}$ symptom associations remained and were nearly identical to values obtained from regression models which did not include a dust variable. No evidence of a dust $\mathrm{SO}_{2}$ interaction effect was present.

\section{SULPHUR DIOXIDE AND SMOKING SYNERGISM}

$A$ greater than additive (synergistic) effect between smoking and exposure to $\mathrm{SO}_{2}$ was present for most of the symptoms we evaluated, including cough, phlegm, and wheezing on most days or nights, but not for dyspnoea (table 7). Results were similar whether $\mathrm{SO}_{2}$ was measured by cumulative exposure or by average exposure while employed.

\section{Discussion}

Silicon carbide production workers are exposed to several airborne emissions that are thought to damage the respiratory system. Evidence suggests that exposure to mixed dust containing $\mathrm{SiC}$ and small amounts of crystalline silica is responsible for the work related abnormalities found in the chest radiographs and pulmonary function tests of these workers. ${ }^{3613-17}$ Our study suggests, on the other hand, that excess work related respiratory symptoms are associated primarily with the low level $\mathrm{SO}_{2}$ exposures encountered in this industry.

Several symptoms, including phlegm (mucous hypersecretion), wheeze, and mild exertional dyspnoea showed strong, highly significant, dose dependent relations to $\mathrm{SO}_{2}$ measured cumulatively, or by average $\mathrm{SO}_{2}$ exposure while employed. Exposure to $\mathrm{SO}_{2}$ on the last day of employment preceding six months of non-exposure was generally unrelated to pulmonary symptoms; however, misclassification caused by frequent job changes made this measure a poor estimate of true exposure.

The low levels of average $\mathrm{SO}_{2}$ exposure while employed which were associated with pulmonary symptoms should not be confused with daily time weighted average exposure. Average $\mathrm{SO}_{2}$ exposure while employed was a time weighted average of all exposures to $\mathrm{SO}_{2}$ occurring throughout the entire duration of each worker's employment; as such, it was useful as an exposure index to evaluate epidemiological relations in an industry with frequent changes in job assignments. Included in its calculation, however, were long periods when $\mathrm{SO}_{2}$ exposure was low or absent, making the measure numerically very small. Daily exposure to $\mathrm{SO}_{2}$ primarily occurred to $20 \%$ of the workforce assigned to the furnace area and overhead cranes where levels of 1.0 to $1.5 \mathrm{ppm}$ (eight hour TWA) were recorded; other workers were exposed to $0 \cdot 2 \mathrm{ppm}$ or less.

The linear exposure response relations we found for these pulmonary symptoms are consistent with the 
well known direct irritant effects of $\mathrm{SO}_{2}$, and support findings from studies of other industrial workers. Kehoe et al in their classic paper found haemoptysis, chest pain, epistaxis, hacking cough, prolongation of colds, morning cough, nasal irritation, and increased expectoration in refrigerator workers regularly exposed to $30 \mathrm{ppm}$ of $\mathrm{SO}_{2}$ throughout the day..$^{18}$ More recently Skalpe reported a significantly higher frequency of cough, expectoration, and exertional dyspnoea in Norwegian pulp workers when compared with their paper worker counterparts. ${ }^{19}$ Their exposures, which averaged about 12 ppm (range 2-36 $\mathrm{ppm}$ ), were probably overestimated by today's standard because they were calculated from area samples collected over short periods and not weighted for the entire working day. Ferris et al conducted a similar investigation in northern New Hampshire where the most recent exposures to $\mathrm{SO}_{2}$ among pulp workers were about $2 \mathrm{ppm}$ as calculated from area samples weighted for the working day. ${ }^{20}$ Although differences were not statistically significant, pulp workers, especially those who smoked, had higher rates of chronic bronchitis and other non-specific respiratory illnesses when compared with workers in an adjacent paper plant.

Several studies of copper smelter workers also found a greater prevalence of respiratory symptoms associated with low level exposure to $\mathrm{SO}_{2}$. Smith et al reported that workers exposed from 1.0 to $2.4 \mathrm{ppm}$ $\mathrm{SO}_{2}$ measured by eight hour TWA personal samples had raised rates of chronic cough and phlegm when compared with workers whose exposures were less than $1.0 \mathrm{ppm}$, although these findings were not statistically significant. ${ }^{21}$ Archer and Gillam evaluated a much larger cohort, comparing smelter workers with copper miners. ${ }^{22}$ They found highly significant excesses of several symptoms including morning cough, chronic phlegm, mild exertional dyspnoea, and chest tightness on returning to work. An often cited "negative" study also showed increased rates of a combination of symptoms defined by the authors as chronic obstructive lung disease among high exposed current smokers when compared with low exposed smoking controls. ${ }^{23}$

Unlike the variable exposures occurring in pulp mills, copper smelters, and $\mathrm{SiC}$ production operations $\mathrm{SO}_{2}$ emissions in the corn refining industry tend to be low and fluctuate little over the workday. In this industry Fabbri et al found significantly increased wheezing in 57 workers exposed to $\mathrm{SO}_{2}$ levels from 0.6 to $3.2 \mathrm{ppm}$ when compared with 49 unexposed coworkers. ${ }^{24}$ Similarly, Greaves et al described highly significant rates of cough, phlegm, and wheeze in workers exposed to $\mathrm{SO}_{2}$ levels of $3 \mathrm{ppm}$ or greater measured by personal samples and averaged over an eight hour day. ${ }^{25}$ Episodes of wheezing were more frequent at exposures as low as $0.5 \mathrm{ppm}$.

In addition to studies of industrial workers, a lare body of experimental evidence shows that low level $\mathrm{SO}_{2}$ exposure, even below $1.0 \mathrm{ppm}$, may significan affect airway reactivity and induce transient airw\&y narrowing leading to respiratory symptoms and temporary decline in pulmonary function. ${ }^{26-28}$ These effects are greater in asthmatics but occur in normal individuals as well. ${ }^{29}$

In our study pulmonary symptoms were n\&t associated with exposure to respirable dust, despite the presence in the dust of hydrocarbon particles shown by others to be associated with symptoms of chrongt bronchitis. ${ }^{3031}$

Cigarette smoking was significantly associated wiक्षి most of the pulmonary symptoms we evaluated and strong synergistic effect between exposure to $\mathrm{SO}_{2}$ ared cigarette smoking was present. Similar synergy with cigarette smoking has been found in other workeis exposed to $\mathrm{SO}_{2},{ }^{25}$ cotton dust, ${ }^{32} 33$ and grain dust. ${ }^{34} 35^{6} \mathrm{O}$

In conclusion, our study found that low level exposure to $\mathrm{SO}_{2}$ in $\mathrm{SiC}$ production workers was associated with significantly increased rates of severg pulmonary symptoms, including chronic phlegiof, wheezing, and mild dyspnoea. Exposures to SQ primarily occurred to the $20 \%$ of the workforee employed in the furnace area and overhead cranes where fluctuating levels of $\mathrm{SO}_{2}$ were measßred averaging 1.0 to $1.5 \mathrm{ppm}$ over an eight hour day, and irregular instantaneous peaks up to $4 \mathrm{ppm}$ were foung In $\mathrm{SiC}$ production the current permissible exposure limit for $\mathrm{SO}_{2}$ of $5 \mathrm{ppm}$ does not appear to provi㺼 adequate protection from the effects of $\mathrm{SO}_{2}$; rather, the level of $0.5 \mathrm{ppm}$ proposed by NIOSH would be mo\&e appropriate for this industry. ${ }^{36}$

We gratefully acknowledge the support of the com munity health department of the Centre Hospitalier la Mauricie, Shawinigan, Quebec, its director Dr René Tremblay, and members of the Occupational Health Service including $\mathrm{Dr}$ Jean Ménard and Jacques Ciccioli. We especially recognise the cooperation of the workers, the company, and their union.

This study was supported by grants from th Institut de Recherche en Santé et Sécurité au Travaî du Quebec, Montreal, Canada, and by NIEHS Center Grant No: ES0002 to the Harvard School of Puble Health, and was submitted by the principal author to the Harvard University, School of Public Health, partial fulfilment of the requirements for the degree $\not f$ doctor of science.

Requests for reprints to: Dr J W Osterma\&, Community Health Department, Lakeshore Genergl Hospital, 175 Stillview, Suite 310, Pointe-Claire, Quebec, Canada H9R 4S3. 


\section{References}

1 Smith TJ, Hammond SK, Laidlaw F, Fine S. Respiratory exposures associated with silicon carbide production: estimation of cumulative exposures for an epidemiological study. Br J Ind Med 1984;41:100-8.

2 Dufresne A, Lesage J, Perreault G. Evaluation of occupational exposure to mixed dusts and polycyclic aromatic hydrocarbons in silicon carbide plants. Am Ind Hyg Assoc J 1987;48:160-6.

3 Osterman JW, Greaves IA, Smith TJ, et al. Work related decrement in pulmonary function in silicon carbide production workers. Br J Ind Med (in press).

4 Bruusgaard A. Pneumoconiosis in silicon carbide workers. In: Proceedings of the ninth international conference on industrial medicine, London, 1948. 13-7.

5 Peters JM, Smith TJ, Bernstein L, et al. Pulmonary effects of exposure in silicon carbide manufacturing. $\mathrm{Br} J$ Ind Med 1984; 41:109-15.

6 Gauthier JJ, Ghezzo H, Martin RR. Pneumoconiosis following carborundum (silicon carbide) exposure. Am Rev Respir Dis 1985;134:A191.

7 Osterman JW, Brochu D, Thériault G, Greaves IA. Evaluation of the ATS respiratory disease questionnaire among Frenchspeaking silicon carbide production workers. Can J Public Health (in press).

8 Ferris BG. Epidemiology standardization project. Am Rev Respir Dis 1978;118:1-120.

9 Field GB. The application of a quantitative estimate of cough frequency to epidemiological surveys. Int J Epidemiol 1974; 3:135-43.

10 Gandevia BH. Clinical techniques. In: Weill H, Turner-Warwick $M$, eds. Occupational lung disease. New York: Marcel Dekker, 1981:11-33.

11 Hall GJL, Gandevia B. Relationship of the loose cough sign to daily sputum volume. British Journal of Social and Preventive Medicine 1971;25:109-13.

12 Kleinbaum DG, Kupper LL, Morgestern H. Epidemiologic research: principles and quantitative methods. Belmont CA: Wadsworth Inc, 1982.

13 Clark WI, Simmons EB. The dust hazard in the abrasive industry. Journal of Industrial Hygiene 1925;7:345-51.

14 Clark WI. The dust hazard in the abrasive industry: second study. Journal of Industrial Hygiene 1929;11:92-6.

15 Smith AR, Perina AE. Pneumoconiosis from synthetic abrasive materials. Occupational Medicine 1948;5:396-402.

16 Funahashi A, Schlueter DP, Pintar K, et al. Pneumoconiosis in workers exposed to silicon carbide. Am Rev Respir Dis 1984; 129:635-40.

17 Bye E, Eduard W, Gjonnes J, Sobroden E. Occurrence of airborne silicon carbide fibers during industrial production of silicon carbide. Scand J Work Environ Health 1985;11:111-5.

18 Kehoe RA, Machle WF, Kitzmiller K, LeBlanc TJ. On the effects of prolonged exposure to sulfur dioxide. Journal of Industrial Hygiene 1932;14:159-73.
19 Skalpe 1O. Long-term effects of sulfur dioxide exposure in pulp mills. Br J Ind Med 1964;21:69-73.

20 Ferris BG, Burgess WA, Worcester J. Prevalence of chronic respiratory disease in a pulp mill in the United States. $\mathrm{Br} J$ Ind Med 1967;24:26-37.

21 Smith TJ, Peters JM, Reading JC, Castle CH. Pulmonary impairment from chronic exposure to sulfur dioxide in a smelter. Am Rev Respir Dis 1977;116:31-9.

22 Archer VE, Gillam JD. Chronic sulfur dioxide exposure in a smelter. J Occup Med 1978;20:88-95.

23 Lebowitz MD, Burton A, Kaltenborn W. Pulmonary function in smelter workers. J Occup Med 1979;21:255-9.

24 Fabbri L, Mapp C, Furlanis D. Alterazioni respiratorie da esposizione cronica a basse concentrazioni di $\mathrm{SO}_{2}$. Med Lav 1977;68:38-50.

25 Greaves IA, Ferris BG, Burgess WA, Essex D. Respiratory effects of sulfur dioxide $\left(\mathrm{SO}_{2}\right)$ among corn refinery workers. Am Rev Respir Dis 1984;129:A157.

26 Schachter EN, Witek TJ, Beck GJ, et al. Airway effects of low concentrations of sulfur dioxide: dose-response characteristics. Arch Environ Health 1984;39:34-42.

27 Mehlman MA. Current toxicological information as the basis for sulfur dioxide standards. Environ Health Perspect 1983;52: 261-6.

28 Ericsson G, Camner P. Health effects of sulfur oxides and particulate matter in ambiant air. Scand $J$ Work Environ Health 1983;9(suppl 3):1-52.

29 Koenig JQ, Pierson WE, Horike M, Frank R. Effects of inhaled sulfur dioxide $\left(\mathrm{SO}_{2}\right)$ on pulmonary function in healthy adolescents: exposure to $\mathrm{SO}_{2}$ alone or $\mathrm{SO}_{2}$ plus sodium chloride droplet aerosol during rest and exercise. Arch Environ Health 1982;37:5-9.

30 Walker DD, Archibald RM, Attfield MD. Bronchitis in men employed in the coke industry. Br J Ind Med 1971;28:358-63.

31 Mittman C, Pedersen E, Barbela T. Prediction and potential prevention of industrial bronchitis: an epidemiological study of a group of coke oven workers. Am J Med 1974;57:192-9.

32 Fox AJ, Tombleson JBL, Watt A, Wilkie AG. A survey of respiratory disease in cotton textile operatives. $\mathrm{Br} \mathrm{J} \mathrm{Ind} \mathrm{Med}$ 1973;30:42-7.

33 Beck GJ, Schachter EN, Maunder LG, Schilling RSF. A prospective study of chronic lung disease in cotton textile workers. Ann Intern Med 1982;97:645-51.

34 Becklake MR, Jodoin G, Lefort L, et al. A respiratory health study on grain handlers in St Lawrence ports. In: Dosman JA, Cotton DJ, eds. Occupational pulmonary disease. New York: Academic Press, 1980:239-56.

35 Cotton DJ, Graham BL, Li KYR, et al. Effects of grain dust exposure and smoking on respiratory symptoms and lung function. J Occup Med 1983;25:131-41.

36 National Institute for Occupational Safety and Health, US Department of Health, Education and Welfare. NIOSH testimony before Department of Labor: hearing for a proposed standard for sulfur dioxide. Washington NIOSH, 1977. 